\title{
Homeostatic unbalance via HSPA5 gene expression in HepG2C3A cells exposed to $\alpha$-tomatine
}

\section{Desequilíbrio homeostático através da expressão do gene $H S P A 5$ em células HepG2/C3A exposto a $\alpha$-tomatine}

\author{
Mário Sérgio Mantovani ${ }^{1}$, Rafael Canfield Brianese ${ }^{2}$, Catherine Kuhn Jacobs ${ }^{3}$, \\ Daniele Sartori ${ }^{4}$
}

\begin{abstract}
The $\alpha$-tomatine is a glycoalkaloid found in immature tomatoes (Lycopersicon esculetum). Currently, $\alpha$-tomatine has shown anticancer effects due to its anti-proliferative property. Stressors are one of the factors contributing to the antiproliferative activity of $\alpha$-tomatine that can modify cellular homeostasis. Among the cell stressors are the endoplasmic reticulum stress response elements, which can be altered leading to cell death. In the course of this study, we verified the expression of genes involved in the stress response of the endoplasmic reticulum in HepG2/C3A cells. The $\alpha$-tomatine reduced the viability of HepG2/C3A cells in a dose-dependent manner. Thus, we selected $2 \mu \mathrm{g} / \mathrm{mL}$ of $\alpha$-tomatine $(62 \%$ in cell viability) to evaluate the gene expressions. After 24 hours of exposure to $\alpha$-tomatine, the level of HSPA5 transcripts was reduced. The HSPA5 chaperone reduced marker is an indicative of homeostasis unbalance with the consequent lack of cellular resistance and, probably, cell death. Our results indicate the involvement of oxidative stress mechanisms in the death of $\mathrm{HepG} 2 / \mathrm{C} 3 \mathrm{~A}$ cells exposed to $\alpha$-tomatine
\end{abstract}

Keywords: a-Tomatine. Antiproliferative. HSPA5 chaperone

\section{Resumo}

A $\alpha$-tomatina é um glicoalcaloide encontrado no tomate imaturo (Lycopersicon esculetum). Atualmente, a $\alpha$-tomatina tem mostrado efeito anticancerígeno devido sua propriedade antiproliferativa. $O$ estresse celular é um dos fatores que contribui para a atividade antiproliferative da $\alpha$-tomatina que pode modificar a homeostase celular. Entre os estressores celulares esta os elementos de resposta ao estresse do retículo endoplasmático, que podem ser alterados, levando à morte celular. No decorrer deste estudo, verificamos que a expressão de genes envolvidos na resposta ao estresse do retículo endoplasmático em células HepG2/C3A. A $\alpha$-tomatina reduziu a viabilidade das células HepG2/C3A de forma dose-dependente. Assim, selecionamos a concentração de $2 \mu \mathrm{g} / \mathrm{mL}$ de $\alpha$-tomatina (viabilidade celular de $62 \%$ ) para avaliar a expressão gênica. Após 24 horas de exposição a $\alpha$-tomatina, o nível de transcrição de HSPA5 foi reduzido. A redução de HSPA5 é um indicativo de desequilíbrio da homeostase, com a consequente falta de resistência celular e, provavelmente, a morte celular. Nossos resultados indicam o envolvimento de mecanismos de estresse oxidativo na morte de células HepG2/C3A exposto a $\alpha$-tomatina e mostram a eficácia do sistema como um futuro candidato para os estudos de terapia de câncer.

Palavras-chave: a-Tomatine. Antiproliferativo. HSPA5 chaperone

\footnotetext{
${ }^{1}$ Departamento de Biologia Geral. Área de Genética: Sub-área de Mutagênese. E-mail: biomsm@uel.br

${ }^{2}$ Departamento de Biologia. Laboratório de Genética Toxicológica. E-mail: rcbrianese@hotmail.com

${ }^{3}$ Departamento de Biologia Geral. Laboratório de Genética Toxicológica. E-mail: catherinej_@hotmail.com

${ }^{4}$ Departamento de Biologia Geral. Laboratório de Genética Toxicológica. E-mail: danibiosart@gmail.com
} 


\section{Introduction}

Glycoalkaloids are chemical compounds naturally produced by the secondary metabolism of some plant species, such as tomatoes (Lycopersicon esculentum), which belong to the genus Solanum Solanum (BARCELOUX, 2008). Tomatoes produce glycoalkaloids, among which $\alpha$-tomatine is the most common. $\alpha$-tomatine is present in immature tomatoes at an average of 4-7 mg per $100 \mathrm{~g}$ of fresh fruit and degrades according to the levels of fruit ripening (KOZUKUE et al., 2004).

Structurally, $\alpha$-tomatine $\quad(\mathrm{C} 50 \mathrm{H} 83 \mathrm{BO} 21)$ consists of tomatidine (aglycon) attached by an $\mathrm{O}$-glycosidic bond to the tetrasaccharide moiety of $\beta$-lycotetraose (composed of D-galactose, D-xylose and 2 molecules of D-glucose) (SHIH et al., 2009).

$\alpha$-Tomatine travels through the digestive tract and reaches the bloodstream without being transformed (MORROW; YANG; SHEIK, 2004). Early studies showed that the $\alpha$-tomatine activity was able to reduce the levels of LDL(Low-Density Lipoprotein), stimulating T lymphocytes and potentiating the antiinflammatory immune response (CHIU; LIN, 2008; FILDERMAN; KOVACS, 1969; FRIEDMAN et al., 2010; MORROW; YANG; SHEIK, 2004; WAKKARY et al., 1967).

Current related studies have shown that $\alpha$-tomatine has anticancer effects. These investigations revealed that its molecule has an antiproliferative property in the HT29 human colon carcinoma cells, HepG2 liver cancer cell lines, A549 and NCI-H460 human lung cells, PC3 human prostate cancer adenocarcinoma cells, EL4 (mouse lymphoma cells) and MCF-7 breast adenocarcinoma cells (LEE et al., 2004; LEE et al., 2011; SHI et al., 2013; SHIEH et al., 2011; SHIH et al., 2009; YANG; WU; MORROW, 2004).

The antiproliferative effect of $\alpha$-tomatine in some cell models has been attributed to cell death. However, the $\alpha$-tomatine antiproliferative mechanism appears to be cell type-specific. Some studies report cell death by apoptosis (LEE et al., 2011). Other works have reported caspaseindependent cell death, including the induction of p53 (CHAO et al., 2012; KÚDELOVÁ et al., 2013).

Stressors that may induce alterations in p53 were observed. The study conducted by Sucha et al. (2013) detected p53 induction in MCF7 cells exposed to $\alpha$-tomatine. Another type of alteration in homeostasis was the loss of ATP in MCF-7 cells exposed to $\alpha$-tomatine observed by Kúdelová et al. (2013). Nevertheless, different forms of cellular stress, including endoplasmic reticulum stress response elements, can change and lead the cells to death.

In our study, we selected the HepG2/C3A cell line (human hepatocellular carcinoma), which is a model for genetic toxicological studies. This cell line comprises phase I and phase II enzymes essential to the metabolism of drugs and carcinogens (DAWSON; ADAMS; WOLF, 1985). Moreover, being a metabolizing cell, one of its key functions is sensitivity or response to the environmental changes through homeostasis (DECAENS et al., 2008). Thenceforth, we evaluated the gene expression and integrated stress response in HepG2/C3A cells related to the cellular response. The results revealed that there is homeostatic unbalancing indicated by the stress response elements of the endoplasmic reticulum (HSPA5), indicative of cell death and absence of resistance of $\mathrm{HepG} 2 / \mathrm{C} 3 \mathrm{~A}$ cells to glycoalkaloid.

\section{Material and Methods}

Human hepatocellular carcinoma (HepG2/C3A) cells and chemicals

The human hepatocellular carcinoma cell line (HepG2/C3A) was obtained from the Cell Bank of Rio de Janeiro, Brazil. The cells were grown in $25 \mathrm{~cm}^{2}$ tissue culture flasks in $5 \mathrm{~mL}$ of DMEM (Dulbecco's Modified Eagle Medium) medium (Gibco, BRL, USA) supplemented with $10 \%$ fetal bovine serum (Gibco, BRL, USA) and antibiotics/ 
antimycotics solution (Gibco, BRL, USA). Under this condition, the cells underwent incubation at $37^{\circ} \mathrm{C}$ in an atmosphere of $5 \% \mathrm{CO}_{2}$.

The synthetic $\alpha$-tomatine (CAS17406-45-0) was prepared in $1 \%$ dimethyl sulfoxide (DMSO) solution and added to the culture flasks. The control flasks were treated with DMSO (1\%). The damageinducing agent used was doxorubicin $(10 \mu \mathrm{g} / \mathrm{mL})$ (CAS 25316-40-9; Adriblastin, Pharmacia, Italy). The concentration of the $10 \mu \mathrm{g} / \mathrm{mL}$ was selected based on preliminary experiments.

\section{Cytotoxicity assay}

For the MTT (3-[4,5-dimethylthiazol-2-yl]2,5-diphenyltetrazolium bromide) assay, $5 \times 10^{3}$ HepG2/C3A cells were incubated for $24 \mathrm{~h}$ in 96-well plates at $37^{\circ} \mathrm{C}$ in a $5 \% \mathrm{CO}_{2}$ atmosphere. The next step consisted of a 24-hour exposure of the cells to $\alpha$-tomatine $1.0,2.0,2.5,3.0$ and $4.0 \mu \mathrm{g} / \mathrm{mL}$. Only HepG2/C3A cells were used as negative control and exposed to $10 \mu \mathrm{g} / \mathrm{mL}$ of doxorubicin as DNA damage agent. The selection of the $\alpha$-tomatine concentration followed the criterion established by Lee et al. (2004). The protocol used for the MTT assay was described by Mosmann (1983). Cell viability was expressed as the percentage relative to the control group $(\mathrm{HepG} / \mathrm{C} 3 \mathrm{~A}$ cells $):$ Cell viability $=\left(\mathrm{A}_{\alpha \text {-tomatine }+}\right.$ HepG2/C3A $\left.-\mathrm{A}_{\text {blank }}\right) /\left(\mathrm{A}_{\mathrm{HepG} / \mathrm{C} 3 \mathrm{~A}}-\mathrm{A}_{\text {blank }}\right) \times 100$, where $\mathrm{A}=$ absorbance. We performed all experiments on three independent biological replicates and three technical replicates. The statistical analysis of the data considered the values of measured parameters compared by ANOVA followed by the Dunnet's multiple comparison test using the GraphPadPrism ${ }^{\circledR} 5$ software $(p<0.05)$.

\section{Real-time reverse transcriptase quantitative} polymerase chain reaction

The quantitative real-time reverse transcriptase polymerase chain reaction (RT-qPCR) was developed according to the Minimum Information for Publication of Quantitative Real-Time PCR Experiments guidelines(BUSTIN etal., 2009). The HepG2/C3A cells $\left(3.0 \times 10^{6}\right.$ cells/flask) underwent pre-incubation for $24 \mathrm{~h}$ and a subsequent exposure to $\alpha$-tomatine. The conditions of treatment were: HepG2/C3A cells, HepG2/C3A cells exposed to $2 \mathrm{~g} / \mathrm{mL}$ of $\alpha$-tomatine for $1 \mathrm{~h}$ only and HepG2/C3A cells exposed to $2 \mu \mathrm{g} / \mathrm{mL}$ of $\alpha$-tomatine for $24 \mathrm{~h}$. The total RNA was extracted using TRIzol LS reagent (Invitrogen, Life Technologies ${ }^{\circledR}$ ).

TheFirst-strand cDNAsynthesis was performed with $200 \mathrm{U} / \mu \mathrm{l}$ reverse transcriptase (M-MLV, Invitrogen, Life Technologies ${ }^{\circledR}$ ), according to the manufacturer's protocol using $1 \mu \mathrm{g}$ of total RNA as template. The qRT-PCR reactions were accomplished using the LightCycler $^{\circledR}$ Nano thermocycler (Roche, Diagnostics). Table 1 shows the oligonucleotides used in these experiments. We used the Platinum ${ }^{\circledR}$ SYBR $^{\circledR}$ Green qPCR Supermix-UDG (Invitrogen, Life Technologies ${ }^{\circledR}$ ) $(10 \mu \mathrm{L})$ as the reaction mixture with the addition of $0.4 \mu \mathrm{M}$ of each primer and $2 \mu \mathrm{L}$ of template cDNA. The final reaction volume was $20 \mu \mathrm{L}$. The PCR thermal cycling conditions included an initial step at $95{ }^{\circ} \mathrm{C}$ for $3 \mathrm{~min} ; 30$ cycles at $95{ }^{\circ} \mathrm{C}$ for $30 \mathrm{sec}, 60{ }^{\circ} \mathrm{C}$ for $30 \mathrm{sec}$ and $72{ }^{\circ} \mathrm{C}$ for $20 \mathrm{sec}$; followed by another step at $95{ }^{\circ} \mathrm{C}$ for 10 sec; and, finally, $40{ }^{\circ} \mathrm{C}$ for $1 \mathrm{~min}$. A thorough melting curve analysis was performed at the end of the reaction with temperatures ranging from $50{ }^{\circ} \mathrm{C}$ to $90{ }^{\circ} \mathrm{C}$. The transcripts assessed were MARK2 (MAP/microtubule affinity-regulating kinase 2), HSPA5 (glucose-regulated protein), HSPA14 (heat shock 70kDa protein 14), TRAF2 (TNF receptor-associated factor 2), EIF $2 A K 3$ (eukaryotic translation initiation factor 2- $\alpha$ kinase 3) and GADD153 (growth arrest and DNA damage-inducible gene 153) (Table 1). The data were normalized against the glyceraldehyde 3- phosphate dehydrogenase (GAPDH) gene. The entire analysis was performed with three independent biological replicates and three 
technical replicates. We obtained the relative the data by the Pair-Wise Fixed Reallocation expression data using the Pfaffl method. Randomization Test in REST ${ }^{\circledR} 2002$ (PFAFFL;

Data variability was expressed as \pm standard HORGAN; DEMPFLE, 2002) software, and deviation (SD) of the mean. We analyzed values of $p<0.05$ were considered significant.

Table 1 - Sequence of primers used in RT-qPCR.

\begin{tabular}{|c|c|c|}
\hline Name & Sequence 5'-3' & Reference \\
\hline GAPDH & $\begin{array}{l}\text { F- 5'GAAGGTGAAGGTCGGAGTC } \\
\text { R- 5' GGAAGATGGTGATGGGATTT }\end{array}$ & $\begin{array}{l}\text { Sugaya, Nakanishi and } \\
\text { Tanzawa, } 2005 \\
\text { with modifications }\end{array}$ \\
\hline$M A R K 2$ & $\begin{array}{l}\text { F- 5' TCCGCGAAGTAAGAATAATGAA } \\
\text { R- 5' GCCACTAGCGTACTCCATGA }\end{array}$ & Present study \\
\hline HSPA5 & $\begin{array}{l}\text { F- 5' GTGGAATGACCCGTCTGTG } \\
\text { R- 5' TGCCCACCTCCAATATCAAC }\end{array}$ & $\begin{array}{l}\text { Song, Yan and Cai, } 2006 \\
\text { with modifications }\end{array}$ \\
\hline HSPA14 & $\begin{array}{l}\text { F-5' CCAGCTGTTGTTGCTTACTCA } \\
\text { R-5' CTGCCCAGGATCTGCTTTAC }\end{array}$ & Present study \\
\hline$E I F 2 A K 3$ & $\begin{array}{l}\text { F-5' CAACCGAGAGGTATTTTGGAA } \\
\text { R-5' GAAAGGAACTGTTTCCATGCT }\end{array}$ & Present study \\
\hline GADD153 & $\begin{array}{l}\text { F- 5’ AGCAGATGTGCTTTTCCAGAC } \\
\text { R- 5' GTCCTCATACCAGGCTTCCA }\end{array}$ & $\begin{array}{l}\text { McCullough et al., } 2001 \\
\text { with modifications }\end{array}$ \\
\hline TRAF2 & $\begin{array}{l}\text { F- 5' GCCCCAAGTTCCCCTTAACT } \\
\text { R- 5' GAATCTGCAAGGGACTCGAC }\end{array}$ & Present study \\
\hline
\end{tabular}

Font: Authors.

\section{Results and Discussion}

Cytotoxicity assays were performed to verify the effects of the exposure of $\alpha$-tomatine on HepG2/C3A cell viability. After $24 \mathrm{~h}$ of exposure, all quantities of $\alpha$-tomatine $(1.0,2.0,2.5,3.0$ and $4.0 \mu \mathrm{g} / \mathrm{mL})$ reduced the HepG2/C3A cell viability $(85 \%, 62 \%, 48 \%, 37 \%$ and 24\%, respectively) (Figure 1). Several studies have described the $\alpha$-tomatine as an antiproliferative agent on cell lines in vitro (KÚDELOVÁ et al., 2013; LEE et al., 2004; LEE et al., 2011; SHI et al., 2013; SHIH et al., 2009; SHIEH et al., 2011; SUCHA et al., 2013; YANG; WU; MORROW, 2004). 
Figure 1 - Percent cell viability of HepG2/C3A cells obtained according to the evaluation of cytotoxicity after 24 hours of $\alpha$-tomatine exposition. The percentage of cell viability was calculated from the absorbance values obtained in cytotoxicity assay. The damage inducing agent was doxorubicin $(10 \mu \mathrm{g} / \mathrm{mL}$ ) (DXR, Adriblastin, Pharmacia). Control: HepG2/C3A cells + DMEM culture medium. The bars represent the standard deviations obtained from three independent experiments. Statistical differences: ${ }^{*} \mathrm{p}<0.05$ compared to control HepG2/C3A cells by Dunnett's test.

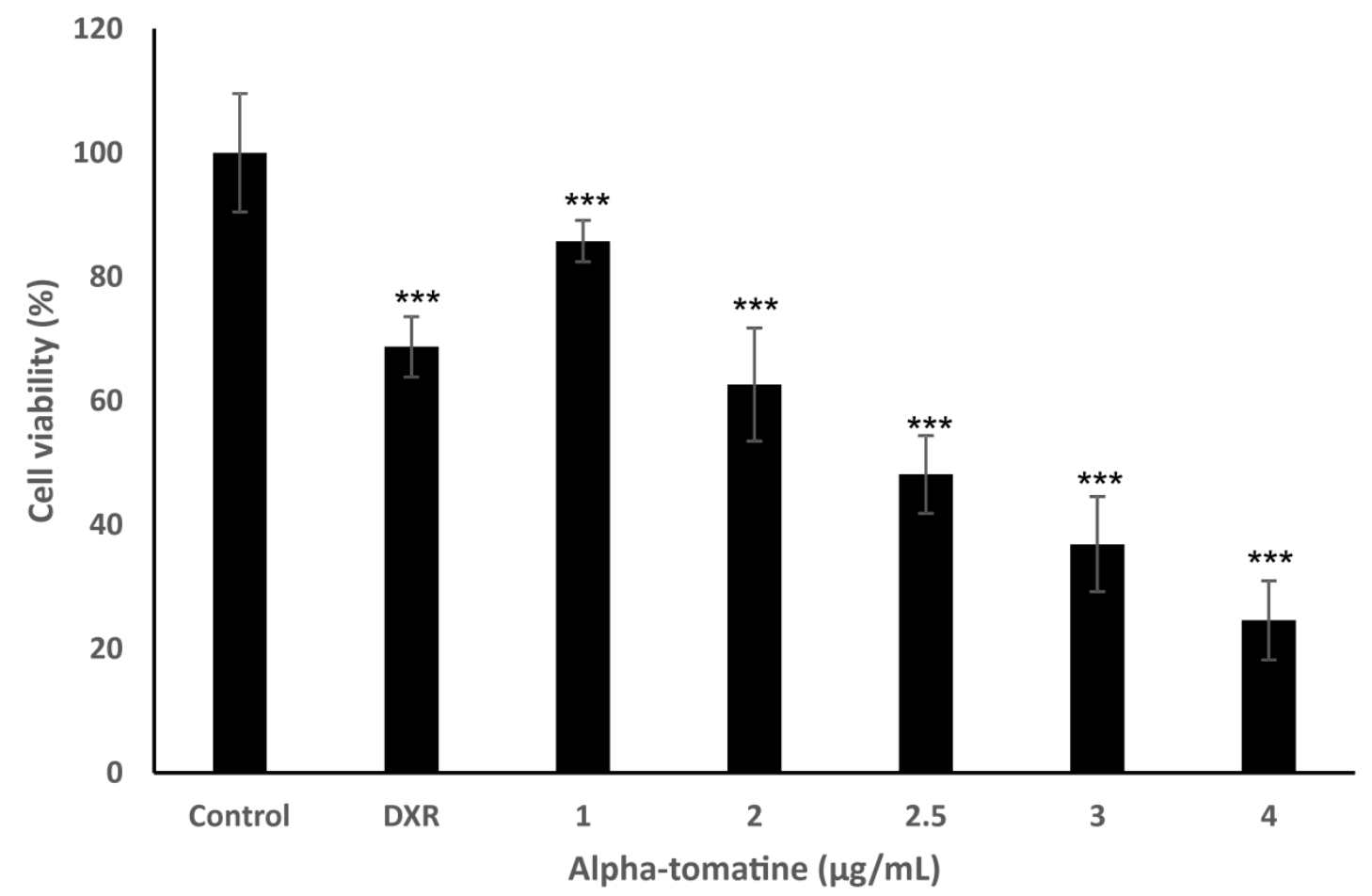

Font: Authors.

The antiproliferative effect of $\alpha$-tomatine has been attributed to its binding with cholesterol in biological membranes unbalancing its polarity and changing the flow of ions. Consequently, the homeostasis leads the subsequent cell death (BLANKEMEYER et al., 1997; GEE et al., 1996; KEUKENS et al., 1995; MORROW; YANG; SHEIK, 2004; YANG; WU; MORROW, 2004).

Researchers agree that $\alpha$-tomatine acts as an antiproliferative agent and the effect is due to cell death. However, the antiproliferative mechanism of $\alpha$-tomatine appears to be cell type-specific. Some authors corroborate that the $\alpha$-tomatine antiproliferative effect induces cell death via apoptosis (CHAO et al., 2012; LEE et al., 2011).
However, recent studies report that $\alpha$-tomatine inhibits cell proliferation and induce caspaseindependent cell death. Furthermore, cell death can occur by different antiproliferative mechanisms, such as stressors, including p53-induced apoptosis (CHAO et al., 2012; KÚDELOVÁ et al., 2013; SUCHA et al., 2013).

After confirming the antiproliferative effect of $\alpha$-tomatine on the HepG2/C3A cells, we selected $2 \mu \mathrm{g} / \mathrm{mL}$ of $\alpha$-tomatine to check the expression of genes involved in endoplasmic reticulum oxidative stress. The HepG2/C3A cell viability was reduced to $62 \%$. Under these conditions, HepG $2 / \mathrm{C} 3 \mathrm{~A}$ cells were exposed to $\alpha$-tomatine for 1 hour and 24 hours to verify the involvement of elements of 
the endoplasmic reticulum stress-related oxidative form of an early or a late stage.

The mRNA levels of the genes (Figure 2) related to the cellular response to endoplasmic reticulum stress specifically in the cell cycle arrest and/or apoptosis in MARK2 and GADD153, did not show substantial differences when the HepG2/C3A cells exposed to $\alpha$-tomatine were compared to HepG2/C3Acells without treatment for $1 \mathrm{~h}$ and $24 \mathrm{~h}$ (1.14-fold and 1.12-fold for $1 \mathrm{~h}$ of exposure, respectively, and 0.7-fold and 0.81fold for $24 \mathrm{~h}$ of exposure, respectively). Nevertheless, there was a reduction in the transcriptional levels, but it was not significant. The same situation occurred with the expression of the TRAF2 gene (1.0-fold and 0.74- fold, for $1 \mathrm{~h}$ and $24 \mathrm{~h}$, respectively). The reduction in gene expression is indicative of early impaired cellular homeostatic unbalance.

The transcripts of HSPA5, HSPA14 and EIF $2 K 3$ genes have not significantly changed after $1 \mathrm{~h}$ of exposure to $\alpha$-tomatine (1.2-fold, 1.1-fold and 0.82-fold, respectively) when compared to HepG2/ C3A control cells. Thus, after $24 \mathrm{~h}$ of exposure we observed a slight, non-significant reduction in gene transcripts HSPA14 - 0.60-fold, EIF2K3 0.69-fold. However, HSPA5 (0.53-fold) was an exception and underwent a significant reduction in the transcriptional level.

Figure 2 - Relative expression of MARK2, HSPA5, HSPA14, TRAF2, EIF2AK3 and GADD153 genes after $1 \mathrm{~h}$ and $24 \mathrm{~h}$ of $\alpha$-tomatine exposition in HepG2/C3A cells. Data were normalized with GADPH gene. Control: HepG2/C3A cells + DMEM culture medium. Statistically significant difference was performed as REST-384 software parameters (PFAFFL; HORGAN; DEMPFLE, 2002).

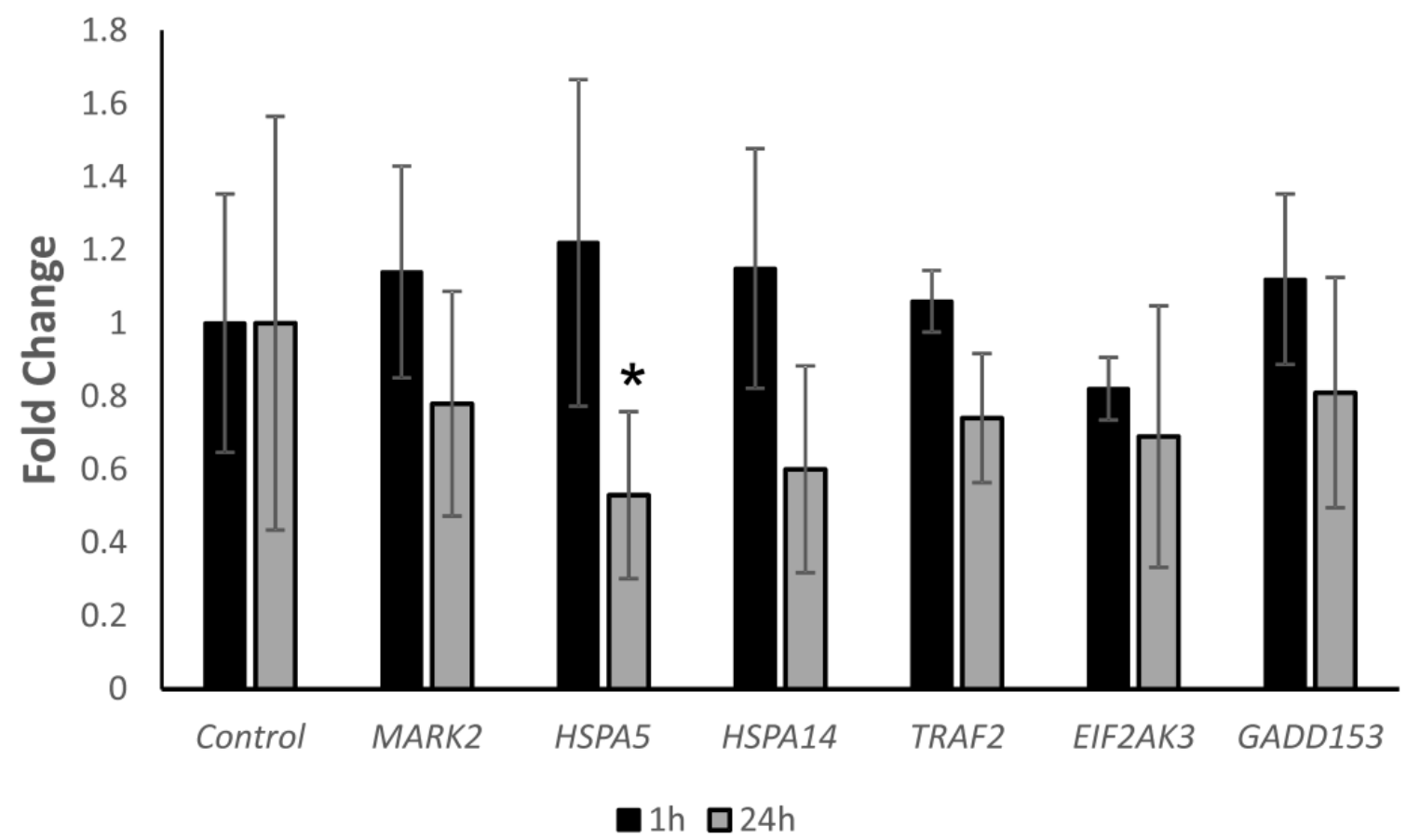

Font: Authors.

In the event of stressor situations, the UPR (Unfolded Protein Response - UPR) pathway must be activated to maintain the cell homeostasis. The UPR pathway can be activated by the endoplasmic reticulum chaperone HSPA5 (GRP78), a component of the transcriptional complex IRE1 (ERN1), ATF6 and PERK (EIF2K3) (FORMAN; LEE; TROJANOWSKI, 2003). 
Under stress, HSPA5 dissociates from the complex. Such dissociation generates a potent transcription factor for UPR gene expression activating signaling pathways to maintain homeostasis (HOTAMISLIGIL, 2010; PFAFFENBACH; LEE, 2010; TODD; LEE; GLIMCHER, 2008). Induced HSPA5 has been used as possible activation markers of the antiapoptotic and antiproliferative agents in tumor cells creating a mechanism of resistance (KIM et al., 2006; LIU et al., 2007; MILOSZEWSKA et al., 2010; ROSATI et al., 2010; ROUE et al., 2011; TAN et al., 2011). On the other hand, the induction of anti-HSPA 5 functions as an apoptotic protein, forming caspase 7 and 12 complexes, keeping them inactive and blocking their proapoptotic function (REDDY et al., 2003).

Conversely, in this study, the HSPA5 expression was inhibited ( 0.53 fold) as a result of the exposure of HepG2/C3A cells to $\alpha$-tomatine for 24 hours. The HSPA5 inhibited expression indicates that the HepG2/C3A cells are probably being forwarded to cell death by a non-apoptotic mechanism, as a result of the above-described induction of HSPA5.

\section{Conclusions}

The reduced expression of HSPA5 provided a new insight into HepG2/C3A cells, indicating that they are not resistant to $2 \mu \mathrm{g} / \mathrm{mL}$ of the $\alpha$-tomatine when exerting their control mechanism to maintain or recover cellular homeostasis. Our results corroborate the involvement of oxidative stress mechanisms in the death of HepG2/ C3A cells exposed to $\alpha$-tomatine and show the effectiveness of the system as a future candidate for cancer therapy studies.

\section{Acknowledgements}

This research was support by CNPq, CAPES and Fundação Araucária, Brazil.

\section{Declaration of interest}

The authors declare no conflict of interest exist.

\section{References}

BARCELOUX, D. G. Potatoes, tomatoes, and solanine toxicity (Solanum tuberosum L., Solanum lycopersicum L.). In: . Medical toxicology of nature substances. Hoboken: J. Wiley, 2008. p. 77-83.

BLANKEMEYER, J. T.; WHITE, J. B.; STRINGER, B. K.; FRIEDMAN, M. Effect of alpha-tomatine and tomatidine on membrane potential of frog embryos and active transport of ions in frog skin. Food and Chemical Toxicology, Oxford, v. 35, n. 7, p. 639-646, 1997.

BUSTIN, S. A.; BENES, V.; GARSON, J. A.; HELLEMANS, J.; HUGGETT, J.; KUBISTA, M.; MUELLER, R.; NOLAN, T.; PFAFFL, M. W.; SHIPLEY, G. L.; VANDESOMPELE, J.; WITTWER, C. T. The MIQE guidelines: the minimum information for publication of quantitative real-time PCR experiments. Clinical Chemistry, Baltimore, v. 55, n. 4, p. 611-622, 2009.

CHAO, M. W.; CHEN, C. H.; CHANG, Y. L.; TENG, C. M.; PAN, S. L. $\alpha$-Tomatine mediated anti-cancer activity in vitro and in vivo through cell cycle and caspase independent pathways. PLos One, San Francisco, v. 7, n. 9, p. e-44093, 2012.

CHIU, F. L.; LIN, L. K. Tomatidine inhibits iNOS and COX-2 through suppression of NF-KappaB and JNK pathways in LPS-stimulated mouse macrophages. FEBS Letter, Amsterdam, v. 582, n. 16, p. 2407-2412, 2008.

DAWSON, J. R.; ADAMS, D. J.; WOLF, C. R. Induction of drug metabolizing enzymes in human liver cell line HepG2. FEBS Letters, Amsterdam, v. 183, n. 2, p. 219-222, 1985.

DECAENS C, DURAND M, GROSSE B, CASSIO D. 2008. Which in vitro models could be best used to study hepatocyte polarity? Biology of the Cell 100:387-398.

FILDERMAN, R. B.; KOVACS, B. A. Antiinflammatory activity of the steroid alkaloid glycoside, tomatine. British Journal of Pharmacology, London, v. 37, n. 3, p. 748-755, 1969. 
FORMAN, M. S.; LEE, V. M. Y.; TROJANOWSKI, J. Q. Unfolding pathways in neurodegenerative disease. Trends in Neurosciences, Amsterdam, v. 26, n. 8, p. 407-410, 2003.

FRIEDMAN M, LEVIN CE, LEE S, KIM H, LEE I, BYUN J, KOZUKUE N. 2009. TomatineContaining Green Tomato Extracts Inhibit Growth of Human Breast, Colon, Liver, and Stomach Cancer Cells. Journal of Agricultural and Food Chemistry. 57:5727-5733.

GEE, J. M.; WORTLEY, G. M.; JOHNSON, I. T.; PRICE, K. R.; RUTTEN, A. A. J. J. L.; HOUBEN, G. F.; PENNINKS, A. H. Effects of saponins and glycoalkaloids on the permeability and viability of mammalian intestinal cells and on the integrity of tissue preparations in vitro. Toxicology in Vitro, Oxford, v. 10, n. 2, p. 117-128, 1996.

HOTAMISLIGIL, G. S. Endoplasmic reticulum stress and the inflammatory basis of metabolic disease. Cell, Cambridge, v. 140, n. 6, p. 900-917, 2010.

KEUKENS, E. A. J.; VRIJE, T.; VAN DER BOOM, C.; DE WAARD, P.; PLASMA, W. H. H.; THIEL, F.; CHUPIN, V.; JONGEN, D. M. F.; KRUJIFF, B. Molecular basis of glycoalkaloid induced membrane disruption. Biochimica et Biophysica Acta, Amsterdam, v. 1240, n. 2, p. 216-228, 1995.

KIM, Y; LILLO, A. M.; STEINIGER, S. C. J.; LIU, Y.; BALLATORE, C.; ANICHINI, A.; MORTARINI, R.; KAUFMANN, G. F.; ZHOU, B.; FELDING-HABERMANN, B.; JANDA, K. D. Targeting heat schok proteins on cancer cells: selection, characterization, and cell-penetrating properties of a peptidic GRP78 ligand. Biochemistry, Washington, v. 45, n. 31, p. 9434-9444, 2006.

KOZUKUE, N.; HAN, J.; LEE, K.; FRIEDMAN, M. Dehydrotomatine and $\alpha$-tomatine content in tomato fruits and vegetative plant tissues. Journal of Agricultural and Food Chemistry, Washington, v. 52, n. 7, p. 2079-2083, 2004.

KÚDELOVÁ, J.; SEIFRTOVÁ, M.; SUCHÁ, L.; TOMŠÍK, P.; HAVELEK, R.; ŘEZÁČOVÁ, M. DNA damage in human leukemic MOLT-4 cells. Journal of Applied Biomedicine, Poland, v. 11, p. 93-103, 2013.
LEE, K. R.; KOZUKUE, N.; HAN, J. S.; PARK, J. H.; CHANG, E. Y.; BAEK, E. J.; CHANG, J. S.; FRIEDMAN, M. Glycoalkaloids and metabolites inhibit the growth of human colon (HT29) and liver (HepG2) cancer cells. Journal of Agricultural and Food Chemistry, Washington, v. 52, n. 10, p. 2832-2839, 2004.

LEE, S. T.; WONG, P. F.; CHEAH, S. C.; MUSTAFA, M. R. Alpha-tomatine induces apoptosis and inhibits nuclear factor-kappa B activation on human prostatic adenocarcinoma PC-3 cells. PLos One, San Francisco, v. 6, n. 4, p. e18915, 2011.

LIU, Y.; STEININGER, S. C. J.; KIM, Y.; KAUFMANN, G. F.; FELDING-HABERMANN, B.; JANDA, K. D. Mechanistic studies of a peptidic GRP78 ligand for cancer cell-specific drug delivery. Molecular Pharmaceutics, Washington, v. 4, p. 435-447, 2007.

MCCULLOUGH, K. D.; MARTINDALE, J. L.; KLOTZ, L. O.; AW, T. Y.; HOLBROOK, N. J. Gadd153 sensitizes cells to endoplasmic reticulum stress by dowm-regulation $\mathrm{Bcl} 2$ and perturbing the cellular redox state. Molecular and Cellular Biology, Cary, v. 21, n. 4, p. 1249-1259, 2001.

MILOSZEWSKA, J.; GOS, M.; PREYZBYSZEWSKA, M.; TREMBACZ, H.; KORONKIEWICZ, M.; JANIL, P. Mouse sarcoma L1 cell line holoclones have a stemness signature. Cell Proliferation, Oxford, v. 43, n. 3, p. 229-234, 2010.

MORROW, W. J. W.; YANG, Y.; SHEIK, N. A. Immunobiology of the tomatine adjuvant. Vaccine, Amsterdam, v. 22, n. 19, p. 2380-2384, 2004.

MOSMANN, T. Rapid colorimetric assay for cellular growth and survival: application to proliferation and cytotoxicity assays. Journal of Immunological Methods, Amsterdam, v. 65, n. 1-2, p. 55-63, 1983.

PFAFFENBACH, K. T.; LEE, A. S. The critical role of GRP78 in physiologic and pathologic stress. Current Opinion in Cell Biology, Philadelphia, v. 23, n. 2, p. 1-7, 2010. 
PFAFFL, M. W.; HORGAN, G. W. DEMPFLE, L. Relative expression software tool (RESTC) for groupwise comparison and statistical analysis of relative expression results in real-time PCR. Nucleic Acids Research, London, v. 30, n. 9, e36, 2002.

REDDY, R. K.; MAO, C.; BAUMEISTER, P.; AUSTIN, R. C.; KAUFMAN, R. J.; LEE, A. S. Endoplasmic reticulum chaperone protein GRP78 protects cells from apoptosis induced by topoisomerase inhibitors. Journal of Biological Chemistry, Baltimore, v. 278, n. 23, p. 20915-20924, 2003.

ROSATI, E.; SABATINI, R.; RAMPINO, G.; DEFALCO, F.; DILANNI, M.; FALZETTI, F.; FETTUCCIARI, K.; BARTOLI, A.; SCREPANTI, I.; MARCONI, P. Novel targets for endoplasmic reticulum stress-induced apoptosis in B-CLL. Blood, New York, v. 116, n. 15, p. 2713-2723, 2010.

ROUE, G.;PEREZ-GALAN,P.;MOZOS,A.;LOPEZGUERRA, M.; XARGAY-TORRENT, S.; ROSICH, L.; SABORIT-VILLARROYA, I.; NORMANT, E.; CAMPO, E.; COLOMER, D. The Hsp90 inhibitor IPI-504 overcomes bortezomib resistance in mantle cell lymphoma in vitro and in vivo by downregulation of the prosurvival ER chaperone BIP/GRP78. Blood, New York, v. 117, n. 4, p. 1270-1279, 2011.

SHI, M. D.; SHIH, Y. W.; LEE, Y. S.; CHENG, Y. F.; TSAI, L. Y. Suppression of 12-O-tetradecanoylphorbol13-acetate-induced MCF-7 breast adenocarcinoma cells invasion/migration by $\alpha$-tomatine through activation $\mathrm{PKC} / \mathrm{ERK} / \mathrm{NF}-\mathrm{kB}-\mathrm{dependent}$ MMP2/MMP-9 expressions. Cell Biochemistry and Biophysics, Totowa, v. 66, n. 1, p. 161-174, 2013.

SHIEH, J. M.; CHENG, T. H.; SHI, M. D.; WU, P. F.; CHEN, Y.; KO, S. C.; SHIH, Y. W. $\alpha$-Tomatine suppresses invasion and migration of human nonsmall cell lung cancer NCI-H460 cells through inactivating $\mathrm{FAK} / \mathrm{PI} 3 \mathrm{~K} / \mathrm{Akt}$ signaling pathway and reducing binding activity of NF-кB. Cell Biochemistry Biophysics, Totowa, v. 60, n. 3, p. 297-310, 2011.

SHIH, Y. W.; SHIEH, J. M.; WU, P. F.; LEE, Y. C.; CHEN, Y. Z.; CHIANG, T. A. $\alpha$-Tomatine inactivates $\mathrm{PI} 3 \mathrm{~K} / \mathrm{Akt}$ and ERK signaling pathways in human lung adenocarcinoma A549 cells: effect on metastasis. Food and Chemical Toxicology, Oxford, v. 47, n. 8, p. 1985-1995, 2009.
SONG, L. H.; YAN, H. L.; CAI, D. L. Gene expression profiles in the liver of mice irradiated with (60)Co gamma rays and treated with soybean isoflavone. Europe Journal of Nutrition, Darmstadt, v. 45, n. 7, p. 406-417, 2006.

SUCHA, L.; HROCH, M.; REZACOVA, M.; RUDOLF, E.; HAVELEK, R.; SISPERA, L.; CMIELOVA, J.; KOHLEROVA, R.; BEZROUK, A.; TOMSIK, P. The cytotoxic effect of $\alpha$-tomatine in MCF-7 human adenocarcinome breast cancer cells depends on its interaction with cholesterol in incubation media and does not involve apoptosis induction. Oncology Reports, Athens, v. 30, n. 6, p. 2593-2602, 2013.

SUGAYA, S.; NAKANISHI, H.; TANZAWA, H. Down-regulation of SMT3A gene expression in association with DNA synthesis induction after $\mathrm{X}$-ray irradiation in nevoid basal cell carcinoma syndrome (NBCCS) cells. Mutation Research, Amsterdam, v. 578, n. 1, p. 327-332, 2005.

TAN, S. S.; AHMAD, I.; BENNETT, H. L.; SINGH, L.; NIXON, C.; SEYWRIGHT, M.; BAMETSON, R. J.; EDWARDS, J.; LEUNG, H. Y. GRP78 upregulations is associated with androgen receptor status, Hsp70-Hsp90 client proteins and castrateresistant prostate cancer. The Journal of Pathology, London, v. 223, n. 1, p. 81-87, 2011.

TODD, D. J.; LEE, A. H.; GLIMCHER, L. H. The endoplasmic reticulum stress response in immunity and autoimmunity. Nature Review Immunology, London, v. 8, n. 9, p. 663-674, 2008.

WAKKARY, J. A.; KOVACS, B. A.; GOODFRIEND, L.; ROSE, B. Isolation of antihistamine like substances from crown gall of tomato. Excerpta Medica International Congress, Amsterdam, v. 144, p. 4, 1967.

YANG, Y. W.; WU, C. A.; MORROW, W. J. W. The apoptotic and necrotic effects of tomatine adjuvant. Vaccine, Amsterdam, v. 22, n. 17, p. 2316-2327, 2004. 
Brianese, R. C. et al. 